\title{
Corrigendum: The church and poverty alleviation in Nigeria
}

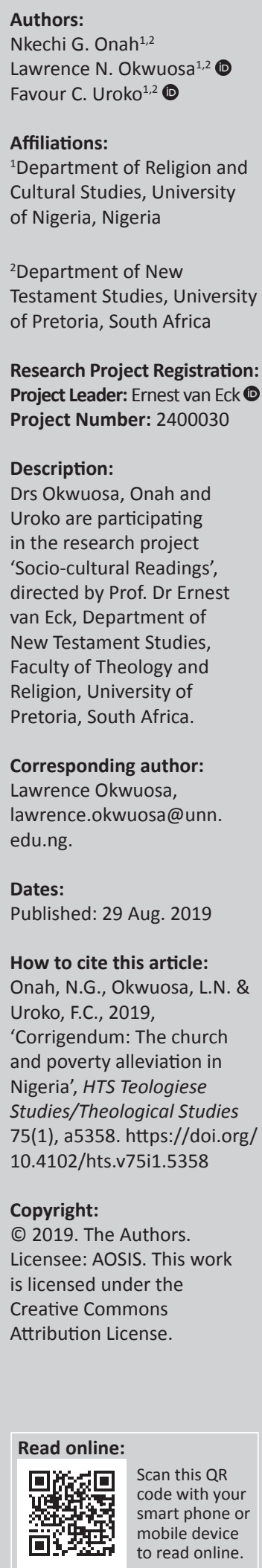

Copyright:

(C) 2019. The Authors. Licensee: AOSIS. This work is licensed under the Creative Commons Attribution License.

In the version of this article initially published, the corresponding author was incorrectly listed as Favour Uroko, favourchukwu44@gmail.com. The corresponding authors' credentials is hereby updated to Lawrence N. Okwuosa, lawrence.okwuosa@unn.edu.ng.

This correction does not alter the study's findings of significance or overall interpretation of the study results. The authors' apologises for any inconvenience that this omission may have caused. 


\section{The church and poverty alleviation in Nigeria}

\begin{tabular}{|c|c|}
\hline \multicolumn{2}{|c|}{$\begin{array}{l}\text { Authors: } \\
\text { Nkechi G. Onah } \\
\text { Lawrence N. Okwuosa } \\
\text { Favour C. Uroko } \\
\text { Fan }\end{array}$} \\
\hline $\begin{array}{l}\text { Affiliations: } \\
{ }^{1} \text { Department } \\
\text { Cultural Studie } \\
\text { of Nigeria, Nig }\end{array}$ & $\begin{array}{l}\text { Religion and } \\
\text { eria University }\end{array}$ \\
\hline $\begin{array}{l}{ }^{2} \text { Department } \\
\text { Testament Stu } \\
\text { of Pretoria, So }\end{array}$ & $\begin{array}{l}\text { f New } \\
\text { dies, University } \\
\text { uth Africa }\end{array}$ \\
\hline $\begin{array}{l}\text { Research Proj } \\
\text { Registration: } \\
\text { Project Leade } \\
\text { van Eck (D) } \\
\text { Project Numb }\end{array}$ & $\begin{array}{l}\text { ect } \\
\text { r: Ernest } \\
\text { er: } 2400030\end{array}$ \\
\hline $\begin{array}{l}\text { Description: } \\
\text { Drs Okwuosa, } \\
\text { Uroko are part } \\
\text { the research p } \\
\text { 'Socio-cultural } \\
\text { directed by Pr } \\
\text { van Eck, Depa } \\
\text { Testament Stu } \\
\text { of Theology ar } \\
\text { University of P } \\
\text { South Africa. }\end{array}$ & $\begin{array}{l}\text { Onah and } \\
\text { ticipating in } \\
\text { roject } \\
\text { Readings', } \\
\text { of. Dr Ernest } \\
\text { rtment of New } \\
\text { dies, Faculty } \\
\text { d Religion, } \\
\text { 'retoria, }\end{array}$ \\
\hline $\begin{array}{l}\text { Correspondin } \\
\text { Favour Uroko, } \\
\text { favourchukwu }\end{array}$ & $\begin{array}{l}\text { g author: } \\
\text { 44@gmail.com }\end{array}$ \\
\hline $\begin{array}{l}\text { Dates: } \\
\text { Received: } 08 \mathrm{C} \\
\text { Accepted: } 231 \\
\text { Published: } 23\end{array}$ & $\begin{array}{l}\text { ct. } 2017 \\
\text { Mar. } 2018 \\
\text { Aug. } 2018\end{array}$ \\
\hline $\begin{array}{l}\text { How to cite th } \\
\text { Onah, N.G., Ol } \\
\text { Uroko, F.C., } 20 \\
\text { and poverty al } \\
\text { Nigeria', HTS T } \\
\text { Studies/Theolc } \\
74(1), 4834 \text {. h } \\
\text { org/10.4102/ }\end{array}$ & $\begin{array}{l}\text { is article: } \\
\text { kwuosa, L.N. \& } \\
\text { 18, 'The church } \\
\text { leviation in } \\
\text { eologiese } \\
\text { ogical Studies } \\
\text { ttps://doi. } \\
\text { its.v74i1.4834 }\end{array}$ \\
\hline $\begin{array}{l}\text { Copyright: } \\
\text { (C) 2018. The A } \\
\text { Licensee: AOS } \\
\text { is licensed unc } \\
\text { Creative Comn } \\
\text { Attribution Lic }\end{array}$ & $\begin{array}{l}\text { uthors. } \\
\text { IS. This work } \\
\text { ler the } \\
\text { nons } \\
\text { ense. }\end{array}$ \\
\hline Read online: & \\
\hline 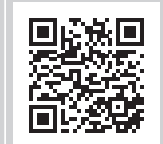 & $\begin{array}{l}\text { Scan this QR } \\
\text { code with your } \\
\text { smart phone or } \\
\text { mobile device } \\
\text { to read online. }\end{array}$ \\
\hline
\end{tabular}

The apparent disconnection between Nigeria's endowment in natural resources and the level of poverty has become a cause for concern, with a serious impact on the development of the nation. To address the poverty issue, the Nigerian government has designed various programmes. Drawing data from official documents and other relevant materials, this article examines such poverty eradication programmes. The article argues that as laudable as they appear, these policies and programmes have failed because of corruption and poor design and implementation, among others. This calls for other stakeholders to be involved in eradicating poverty in Nigeria. This article thus looks at what the Catholic Church is doing to reduce poverty for peace and sustainable development in Nigeria. It suggests that collaborative governance is the key to poverty eradication, peace and sustainable development in Nigeria. The descriptive phenomenological method was employed in the study.

\section{Introduction}

Poverty has been identified as a serious problem in Nigeria (ActionAid Nigeria 2015; Taiwo \& Agwu 2016; Ucha 2010). Poverty has been defined in a variety of ways. One such view defines poverty as a deficiency and degraded human material conditions that inhibits the optimal realisation of basic needs such as food, health, education, shelter and clothing (Ighadalo 2012:52). United Nations (1998), cited in Gordon (2005), gave a more comprehensive definition of poverty when it asserted that:

Fundamentally poverty is a denial of choices and opportunities, a violation of human dignity. It means lack of basic capacity to participate effectively in society. It means not having enough to feed and cloth a family, not having a school or clinic to go to, not having the land on which to grow one's food or a job to earn one's living, not having access to credit. It means insecurity, powerlessness and exclusion of individuals, households and communities. It means susceptibility to violence, and it often implies living on marginal or fragile environments, without access to clean water or sanitation. (p. 4)

The poor are people who have insufficient income and inadequate food intake, lack basic healthcare, lack shelter and safe drinking water, have poor environmental cleanliness, lack access to basic education and skills, are ignorant of fundamental human rights and lack access to information (Barnes 2010).

In Nigeria, poverty has continued to ravage the greater populace despite its plentiful agricultural resources and oil wealth. Some of the crimes being committed in Nigeria, such as human trafficking, kidnapping, armed robbery and various insurgencies, may be linked to poverty (Ayegba 2015). These crimes have been hampering peace and sustainable development of the country. Nigeria is the 10th largest producer of crude oil in the world and the sixth largest exporter among Organization of Petroleum Exporting Countries (OPEC)s (Odeh 2011), in addition to other untapped solid mineral resources. Nigeria has retrogressed to become one of the 25 poorest countries in the world (Ekpe, 2011). Seventy per cent of Nigerians live on less than US $\$ 1.25$ a day (Aidelunuoghene 2014:117). Poverty is especially severe in rural areas, where up to $80 \%$ of the population live below the poverty line (International Fund for Agricultural Development 2012:2).

Today many Nigerians are migrating to western countries because of poverty and unemployment. Nigeria is among the 189 countries that endorsed the Millennium Development Goals (MDGs) in 2000, which has 'eradication of extreme poverty and hunger' by 2015 as its number one goal. To fight poverty, the Nigerian government has over the years instituted programmes and policies for poverty eradication and/or reduction. However, poverty has persisted and has continued to create socio-economic challenges in the country. It has become evident that the government alone cannot eradicate this malaise, hence the question whether the church has to play any role. Why have government's poverty reduction programmes failed? How can the church bring about better living standards for the vast majority of Nigerians? Focusing on the Catholic Church, this article tries to answer these questions. 


\section{Trends of poverty in Nigeria}

Poverty has persisted and has become a clog to socioeconomic development in Nigeria. The International Food Policy Research Institute (2010) in discussing poverty levels in Nigeria from 1980 to 2004 notes that based on available data, it is estimated that approximately 69 million (or 54.4\%) Nigerians lived in poverty in 2004, an increase of more than $24 \%$ since 1980. The report further explains that Nigeria's national poverty profile shows that the incidence of poverty has generally been on the rise since 1980, with two significant dips during 1985-1992 and 1996-2004. The national poverty incidence was 65.6\% in 1996 and declined to $54.4 \%$ in 2004 . The predominance of rural over urban poverty has been consistent during 1996-2004. In 1996, about 70\% of rural households were poor, as compared with $58 \%$ of the urban households. In 2004, the incidence of urban poverty declined more rapidly than rural poverty, with $64 \%$ of rural households being poor (a $6 \%$ decrease), while urban poverty decreased by $15 \%-43 \%$. The same study indicated that poverty incidence, debt and severity were higher in all three northern regions. In a similar report, the National Bureau of Statistics (2012), cited in Ajulor (2013:239), observed that the 17 million people who were reported poor in 1980 had risen to 112 million in 2010. There was an increase in poverty level to $69.0 \%$, with $73.2 \%$ rural poverty compared with an urban poverty level of $61.8 \%$ in 2010.

Today the story is not much different, as greater numbers of Nigerians are classified as poor. The United Nations Development Programme estimated the proportion of Nigerians living in absolute poverty as at 2015 to be $62.6 \%$ of its population, while the Human Development Index was put at 0.514 and ranked 152 out of 188 countries (National Institute for Policy and Strategic Studies 2016).

\section{Poverty eradication and/or alleviation strategies and programmes in Nigeria}

The Federal government's concern over increasing poverty among Nigerians and the need for its eradication has led to the establishment of various poverty eradication and alleviation policies and programmes. Over the years, successive governments have made attempts at alleviating poverty through establishment of some programmes. Such programmes include Operation Feed the Nation (OFN), which was launched in 1979 by Gen. Olusegun Obasanjo with a specific aim towards increasing food

\begin{tabular}{lccc}
\multicolumn{4}{l}{ TABLE 1: The summary of poverty profile. } \\
\hline Year & $\begin{array}{c}\text { Poverty } \\
\text { incidence (\%) }\end{array}$ & $\begin{array}{c}\text { Estimated population } \\
\text { (million) }\end{array}$ & $\begin{array}{c}\text { Population in poverty } \\
\text { (million) }\end{array}$ \\
\hline 1980 & 27.2 & 65 & 17.1 \\
1985 & 46.3 & 75 & 34.7 \\
1992 & 42.7 & 91.5 & 39.2 \\
1996 & 65.6 & 102.3 & 67.1 \\
2004 & 54.4 & 126.3 & 68.7 \\
2010 & 69.0 & 163 & 112.47 \\
\hline
\end{tabular}

Source: National Bureau of Statistics. HNLSS, 2010, Nigeria poverty profile, Abuja, Federal Republic of Nigeria production. His successor Shehu Shagari came up with Green Revolution, which also laid emphasis on food production. Other efforts made by successive governments according to Odion, cited in Barnes (2010:141), include the establishment of the Directorate of Food, Roads and Rural Infrastructure (DFFRI), National Directorate of Employment (NDE), Better Life Programme (BLP), the Peoples' Bank of Nigeria (PBN), Family Support Programme (FSP), Family Economic Advancement Programme (FEAP) and National Economic Empowerment and Development Strategy (NEEDs). The DFFRI was established in 1986 to construct feeder roads to provide rural water supply and rural electrification for the rural areas. The NDE was also established in 1986 to provide training, finance and guidance for unemployed youths. The Better Life Programme, on the other hand, came into existence in 1987 to provide empowerment, self-help and rural development programmes, as well as skills acquisition and healthcare for the rural women. The PBN was established in 1989 to encourage savings and credit facilities for the underprivileged in urban and rural areas, while Community Banks were established in 1990 to operate banking facilities for rural residents and micro enterprises in urban areas. The FSP came on board in 1994 to provide healthcare delivery, child welfare, youth development and so on. The FEAP and its state variant Self-reliance Economic Advancement Programme (SEAP) were initiated to provide credit facilities to support the establishment of cottage industries in rural areas. The poverty alleviation programme (PAP) was an interim measure put in place in 2000 to address the problems of rising unemployment in the society and to increase the productiveness of the economy. It was designed to coordinate and monitor poverty alleviation efforts and ensure that Nigerians were provided with steady sources of income, high purchasing power, quality education, water, healthcare and housing, and stable and affordable power supply.

The National Poverty Eradication Programme (NAPEP) was established in 2001 with the aim of providing 'strategies for the eradication of absolute poverty in Nigeria' (FRN 2001). This programme was aimed at eradicating absolute poverty and it consists of four schemes:

1. Youth Empowerment Scheme (YES)

2. Rural Infrastructure Development Scheme (RIDS)

3. Social Welfare Service Scheme (SOWESS)

4. Natural Resource Development and Conservation Scheme (NRDCS) (Antai \& Anam 2014).

The NAPEP was meant to help the citizenry in skill acquisition and job creation. The programme has the involvement of the federal, state and local governments, international donor agencies, community-based organisations and civil society organisations (Oluwatoyin 2014)

In the area of agriculture, since 1999, Nigeria has initiated different agricultural programmes such as the National Special Programme on Food Security (NSPFS), the Root and Tuber Expansion Programme (RTEP), and recently the Agricultural Promotion Policy (APP). Others are the 
Agricultural Development Programme (ADP), Strategic Grains Reserve Programme (SGRP) and the Agricultural Transformation Agenda (ATA) (2011-2015). The impact of these programmes did not reduce the incidence of poverty in the country, while it still imports N2.2 billion of food annually. The APP (2016-2020) has the potential to meet food security, reverse food importation, promote agricultural export to earn foreign exchange and improve the nation's Gross domestic product (GDP) (National Institute for Policy and Strategic Studies 2016).

The Subsidy Reinvestment and Empowerment Programme (SURE-P) was introduced and inaugurated in 2012. This programme was introduced to alleviate the immediate impact of fuel subsidy removal and escalate economic growth through investments in critically needed infrastructure. The Federal Government of Nigeria committed N525 billion as the federal component of funds for SURE-P, between 2012 and 2015, aside from funds released to states and local governments. Despite these efforts, Nigeria is ranked third among countries with the highest population of extreme poor or people living in abject poverty in the world (National Institute for Policy and Strategic Studies 2016). Hence, these policies and programmes have failed to achieve the desired results.

\section{The problems of poverty reduction programmes in Nigeria}

There are constraints for effective implementation of poverty reduction programmes in Nigeria, which include corruption and mismanagement, ineffective targeting of the poor leading to leakage of benefits to unintended beneficiaries, poor design and implementation, deficient infrastructural facilities, poor funding of programmes and political and policy instability (Obadan 2002). All these point to bad governance and over-centralisation of power which have become the bane of the country. Because of the different and numerous interests in the country, it is difficult to carry out a holistic and comprehensive poverty reduction programme that would fit and satisfy the six geopolitical zones. Although some pocket successes have been made in areas of agriculture, education and provision of primary health care, poverty still remains high in the country. Each government that comes into power relegates what the previous government has started. The constant change in poverty reduction programmes does not allow the people to completely embrace the policies and for the policies to make the expected impact. The gimmick on poverty eradication has become the campaign slogan and means for government officials to enrich themselves at the expense of the poor. In some cases, the philosophy behind these programmes is of little or no relevance for the people. For example, some states of the federation empowered their unemployed graduates with Keke NAPEP and as road sweepers. Even the federal government vouched to give unemployed youths monthly stipends. Innovative as these may seem, they simply impoverish not only the pockets of these poor people who are in dire need but also their minds. It perpetuates poverty and generates dependency. These people lose self-esteem and self-fulfilment.

Proper policy awareness does not always follow the poverty eradication policies. There is the misconception in some places that these poverty eradication programmes are shares of the national cake for the poor. Hence, instead of using loans and other benefits of the programmes to improve the quality and efficiency of their handiwork, poor people like farmers and artisans see it as an opportunity to take care of other pressing family needs. It is not unheard of for some administrators of these programmes to sell forms for these programmes that should have been free to the intended beneficiaries. There are also cases where funds and materials made for internally displaced persons (IDPs) who have lost their sources of livelihood were misused by the officials. These funds and materials are meant to alleviate the poverty of those in the IDP camps. These attitudes discourage and make people lose faith in the programmes.

\section{Poverty eradication in Nigeria: Any hope from the Catholic Church of Nigeria?}

The failure of the government to alleviate or eradicate poverty calls for all the social actors to be involved in handling the issue. In this regard, the role of the Catholic Church becomes relevant. The Catholic Church is very influential, with a rich history of social teachings and actions that could be used in the Nigerian context. Actually, the Catholic Church like other Christian denominations adheres to the teachings of Jesus Christ that uphold in an unequivocal term options for the poor (cf. Lk 4:18, Mt 25:34-36, Lk 6:2021, Jn 13:34). This means that other than feeding the poor spiritually, the Roman Catholic Church also attends to the material needs of the poor.

In the modern time, the church has played a prominent role in the society, especially with regard to poverty and poor people. Like Jesus Christ who identified and cared for the poor, the church strives to free all humans from hunger, misery, oppression, ignorance, institutionalised injustice and hatred which are rooted in humans' selfishness (Achunike 2004:131). The church's option for the poor is part of its vocation in the world. In the words of Oborji (2012):

The Church's care of the poor is not a mere social service which others would as well do, but it is rooted on the very nature of the Church in continuing the redeeming work of Christ of bringing integral salvation to men and women. It is founded on the divine command of love of neighbour. (p. 169)

In order to buttress this aspect of its life in the world, the Nigerian Catholic Church operates a twofold programme of action for the poor. The first consists of the church's teaching apostolate, while the second is the church's pastoral care of the poor. 
Some of the social teachings of the Catholic Church are found in the encyclicals and pastoral letters of the popes and ecumenical councils. In the Second Vatican Council document on Pastoral Constitution on the church in the modern World, Gaudium et Spes (GS), the church states that 'the joy and hope, the grief and anguish of the men and women of our time, especially of those who are poor or afflicted in any way are the joy and hope, the grief and anguish of the followers of Christ as well' (GS1).

In 1891, Pope Leo XIII in his social encyclical Rerum Novarum on the 'condition of labour' affirmed that the church's desire is that the poor should rise above poverty and wretchedness, and should better their condition in life (1891:par. 23). Pope Pius XI in his Quagragesimo Anno (1931) stated the need to pay workers just wages, which are for him a family wage. In view of this, he proposed a social order built on social justice and charity as a panacea for poverty in the world (par. 59). The Mater et Magistra (1961) was written by Pope John XXIII against the indifference of wealthy nations on the hunger, misery and poverty of nations whose citizens are unable to enjoy even elementary human rights. It stresses the solidarity that binds human beings together as members of a common family (par. 157). The same concern was also raised in Pope Paul VI's Populorum Progressio 'Development of the peoples' (1967). The Pope pointed at the threatening world poverty (no. 29) and argued that it is as a result of unjust economic relationships between rich and poor countries (no. 57) and new forms of colonialism and economic manipulation (no. 52). The Pope advocated for solidarity among nations (no. 13) and maintained that the new name for development is peace (no. 76). The apostolic exhortation Evangelii Nuntiandi (1975) by Pope Paul VI states that evangelisation will be incomplete if it did not take account of the unceasing interplay of the gospel and people's social lives, both personal and social. He notes that evangelisation will not be complete without care of the poor. This implies that caring for the poor is very important in the social teaching of the Catholic Church.

With the papacy of Pope John Paul II, the world witnesses a vibrant approach to the issue of world poverty. In 1981, he wrote the encyclical Laborem Exercens on 'Human Work', reiterating the church's concern for the poor, the evil of unemployment, dehumanising social structures and just wage. For him, work and just wage are crucial in human life and in maintaining social imbalance (par. 3). The Pope affirmed that the nature of humanity is to work, because work confers dignity on humans (par. 6). He proposed 'worker solidarity' as a panacea against workers' exploitation and injustice in society. In another encyclical, Sollicitudo rei socialis [the social concerns of the church] (1988), the Pope decried the bastardisation of the world into different categories of first, second and third worlds (art. 14). While lamenting over the overwhelming poverty in the poor countries, he recommended that developing nations should take their fate in their hands and collaborate with each other without violence (art. 39). Though he sought the help of the rich nations, he maintained that the poor nations should not wait for this help that may not come (art. 44).
Pope Francis, the current head of the Catholic Church, in his apostolic exhortation, Evangelii Gaudium (2013), brought newness in the church's social teaching on poverty. For him, the poor has so much to teach the world. In the poor, we experience Jesus who was described by Prophet Isaiah as 'a man of sorrow and grief'. The poor in their difficulties know the sufferings of Christ. They know Christ, and through them we can be evangelised (no. 198).

In all these social teachings, the Catholic Church educates the world on poverty and disabuses people's minds of certain unfounded notions about it. The church affirms that poverty is not accidental and not the result of nature's whims. It has been created by decisions and policies in the socio-economicpolitical realms, and it is a matter of justice and injustice (Kammer 1991). Government policies that undermine social justice give birth to poverty. Hence, the church rejects the claim that poverty is a result of laziness or people's unwillingness to work. She also rejects the notion that wealth, riches, health and prosperity are God's blessings, while poverty and sickness are curses from God and the actions of evil spirits on men. Rather, the church affirms that human freedom that leads to disdain for God and humanity is the cause of poverty. Through different kinds of disobedience to God in terms of hatred, division, materialism and exploitation of natural resources, humanity creates poverty in the world.

The Catholic Church in its social teachings states clearly that poverty is a threat to humanity; hence, it does not direct its teachings to only Catholics or Christians, but to every human being. Every human being must be at the side of the poor. Giving to the poor is simply restoring to them what is theirs by right (1 Jn 3:17). It means doing something, and this forms the second part of the church's initiative against poverty in the world. The second part of the church's programme for the poor is pastoral care of the poor. On 06 January 1967, Paul VI created the Pontifical Commission, 'Justice and Peace'. The commission aims at the complete development of humanity. It was later renamed the Justice, Development and Peace Commission (JDPC) under Pope John Paul II and situated in every Catholic diocese of the world. The work of the JDPC is to gather, synthesise and evaluate studies related to the development of peoples, peace, justice and human rights (Achunike 2004:133). Achunike further noted that the principles and objectives of JDPC include the following:

1. to promote the quality of life for all people

2. to promote human rights (e.g. U.N. Charter on Human Rights)

3. to form and animate groups to participate in their own development

4. to make a preferential option for the poor and marginalised

5. to identify unjust structures and to make corrective action

6. to promote Catholic social teachings

7. to research, document and publish information on social issues

8. to cooperate with international agencies, government and non-governmental organisation (NGOs) for integral development

9. to build channels of dialogue through actions and peace. 
Hence, Olubitan (2014:177) observed that the JDPC is the committee entrusted with the sole responsibility of attending to the church and societal problems, and it is from this perception that the needs of the public are identified and addressed.

The Catholic Bishops' Conference of Nigeria, the organ that unites the Catholic Church across Nigeria, helps to spearhead the teachings of the church and the pastoral care of the faithful. The promotion of human dignity (which coincidently is the theme of 2013 Catholic Bishops Conference of Nigeria meeting), freedom, justice and equity, the defence of the poor, the weak, the marginalised and the oppressed have been the sole aim of the Catholic Bishops' Conference of Nigeria (Olubitan 2014:177). Through the conference, the bishops of the 55 dioceses in Nigeria meet to deliberate on issues concerning the church.

The Catholic Church in Nigeria has established many schools and scholarship schemes to provide education to the masses and has built hospitals, orphanages, old peoples' homes and motherless babies' homes, among others. In Nsukka diocese, for example, there is a scholarship scheme for indigent students. It has also continued to empower rural women by providing loans at a very low interest rate through its microcredit scheme. This exists in all the seven Catholic dioceses of the Onitsha ecclesiastical province. Through the agricultural department of the JPDC, farm produce is shared with the poor. There are women cooperatives and such groups are equipped with garri processing machines. For instance, they have garri processing machines in Opi-Agu and rice mills at Adani and Eha-amufu, Enugu State. Many disadvantaged and physically challenged people have been taken away from the streets, rehabilitated, and employed in many Catholic establishments such as Catholic farms, hospitals, schools and printing press.

Another approach of the Catholic Church in dealing with poverty is in the area of women empowerment. Many women are victims of poverty. For example, the Catholic Diocese of Sokoto raises hope for marginalised women with the help of a small women-training programme by Dominican sisters under the patronage of the local bishop. They established a women's centre within the cathedral complex, where the women are mainly taught catering and fashion design (Olubitan 2014)

In most Catholic dioceses in Nigeria are found sodalities that work assiduously to alleviate poverty in the society. Among these sodalities are Legion of Mary, Saint Vincent de Porres associations and Caritas, which are found in all the Catholic dioceses. There are also other organisations like the Kolping Society in Umuahia Diocese and the Eu-Care Apostolate in Owerri Archdiocese that render selfless service to the people. Many Catholic dioceses in the Owerri ecclesiastical province have established centres where skills such as hair dressing, catering, tailoring, carpentry, tiling and electrical works are learnt for poverty eradication. Every Christmas the Catholic
Archdiocese of Owerri feeds over 500 destitute and physically challenged persons in Imo state (https:www.vanguardngr. com/2009/12). They have established micro-finance banks, which grant loans, give professional advice on business and serve as a means of employment for the teeming population of unemployed in society (Onwuliri 2008).

Catholic Women Organisations (CWOs) in different dioceses distribute food items, such as rice, yam, garri, beans, toiletries, and so on, to the less privileged like the motherless peoples' homes, prisons and leprosy settlement. In 2014, the CWO of St. Anthon's parish, Gbaja, Lagos empowered over 110 individuals from members, non-members and youths, both male and female, in skill acquisition (barbing, gele tying, interior decoration, make-up, and so on, with issuance of certificates to successful candidates) (http://www. stanthonysurulere.org). These charitable works have sacramental symbolism as they are regarded as part of Lenten practice and obligation. Other, smaller, pious organisations in the Catholic Church such as St Anthony and Mary League also join in this act of solidarity with the poor by visiting and sending money, food items and clothes to ameliorate their sufferings.

The Catholic Bishops' Conference of Nigeria, the highest ruling body of the Catholic Church in Nigeria, is also known to engage in poverty reduction programmes. In order to improve the quality of education, it does not only criticise the government for the poor education system, but have also gone further to establish their own universities in various dioceses of Nigeria. This approach and many offers to indigent students have really helped to make education accessible to the poor (http:/ / allafrica.com/stories/201403171755.html).

Special needs schools like Pacelli School for the Blind and Partially Sighted, Lagos and DonGuanelli Centre for handicapped children, and Nnebechkwu in Imo state are under the jurisdiction of the Catholic Church. These schools help to improve the quality of life for physically challenged people by educating and empowering them and making them productive citizens, thereby reducing poverty in society. Pacelli School for the Blind and Partially Sighted, for example, is a boarding school that provides for the welfare of the visually impaired. In addition to catering for their own students, the school assists other visually impaired students from other schools to use their facilities. They are offered courses like Braille reading and writing, daily skills, art and crafts, orientation and mobility. The school is committed to producing graduate students who are independent and able to advance in any field. The school has produced teachers, musicians, lawyers, journalists, business managers, and so on, and has maintained a non-fee paying status (www. educationinnovations.org $>$ program).

Also, the Catholic Bishops' Conference of Nigeria has contributed immensely to the alleviation of the suffering of the victims of Boko Haram insurgency in the North-East of Nigeria and by begging the good spirited Nigerians and 
organisations to come up to the help of these helpless people through the Catholic JDPC/Caritas (http://sundiatapost. com2018/01/17). The Catholic Church has donated relief material such as bags of rice, clothes, oil and money to people in IDPs camps. Prayers for return of peace were also offered (https://www.vanguardngr.com).

The Catholic Church of Nigeria has made vehement protestation against bribery and corruption that impoverish the masses and hamper the proper execution of poverty reduction programmes and sustainable development of the country. On a regular basis, especially through pastoral letters, the Catholic Bishops' Conference has written and warned the government and the entire nation about the negative effects of bribery and corruption on the people. The Episcopal body has composed prayers against bribery and corruption in Nigeria which it encourages the faithful to say.

\section{The Catholic Church's constraints on its poverty reduction programmes in Nigeria}

The Catholic Church in Nigeria is faced with myriad problems as it tries to respond to the poverty situation according to the social teachings of the church. Some of these problems are internal issues, while most others are external. One of the major challenges that the Catholic Church faces today in its poverty reduction programmes is lack of funds. Before the global economic meltdown, the church received funds from its Western counterparts such as Caritas International, Opera San Pietro, Justice and Peace Commission, Catholic Relief Services, The Club of Rome and St. Vincent de Paul Association; however, today the situation is different as it now receives limited funding from them. Local funding is not easy to come by because some corporate organisations, besides battling with the same global economic meltdown, do not have strong social corporate responsibility policies.

Another factor that militates against the Catholic Church's effort to render a perfect poverty reduction programme is conflict of interest with the government. Most often, the federal government views the activities of religious groups, including the Catholic Church of Nigeria, as usurping its role. Such understandings lead to viewing efforts of the Catholic Church as a kind of indictment, politicking and campaigning against the efforts of the sitting government. Sometimes, too, the Catholic Church's teachings and policies are in contrast with that of the government. For example, the issue of birth control, which is believed to be one of the main contributing factors to poverty in developing countries, is approached from different perspectives by the government and the church. While the former advocates for contraceptives to control birth, the latter advocates for natural birth control without any possibility of abortion (The Catholic Bishops' Conference of Nigeria 2014).

Recently, the federal government eliminated the teaching of Christian Religious Knowledge (CRK) in schools. This was like a coup against the Christianity in Nigeria in general and the Catholic Church in particular because CRK forms part of its social and moral teachings (The Catholic Bishops' Conference of Nigeria 2014). The impression is that the attempt of the Federal Ministry of Education to introduce a curriculum that intends to combine the teachings of Christian and Islamic religions in one syllabus could jeopardise Christian family life in the country.

It is not always that the efforts of the Catholic Church to reduce poverty are welcomed. The government does not involve faith-based organisations in poverty reduction programmes. The government would not want the involvement of the church in the poverty reduction programmes because the church will not condone corruption within the system created for poverty reduction in Nigeria (Ani, Chukwuelobe \& Nwankwo 2015). Sometimes also, because of religious bias and suspicion, the Catholic Church's poverty reduction programmes are seen by other religious groups as a kind of proselytism. In view of this, occasionally, the programmes are outrightly rejected and sabotaged. On the other hand, there is the case whereby the programmes target only members of the church, thus being discriminatory.

Furthermore, the church is challenged by its internal bureaucratic structure that encourages the use of its members mostly to execute its programmes. The implication is that sometimes expertise and excellence are traded for incompetence in matters of poverty reduction. In this situation, the good will of the church is not good enough because the programmes suffer seriously. It is also not unknown that some of the staff engaged in the programmes sabotage them for their own selfish interests. The programmes when not fully managed by competent individuals but simply as a matter of people's faith may run into major problems in decision-making, reaching out to people and accountability.

\section{Recommendations}

Notwithstanding all that the Catholic Church is doing to alleviate poverty in Nigeria, there is still much to be done to reduce poverty in Nigeria. These include:

- The Catholic Church in Nigeria must be seen as seriously fighting bribery and corruption by penalising its members who indulge in these unwholesome practices.

- The Catholic community must be vigilant in protecting the rights of the poor in Nigeria. They must constitute themselves at every societal level as watchdogs against any act that undermines the interests of the poor. They must monitor government developmental projects in their areas against vandalism and substandard works.

- The Catholic Church must discourage flagrant exhibitions of wealth and discriminatory titles in the church. The church must always affirm that before God all men are equal. To bring its social teachings on poverty to an understandable and appreciable level, the church has to look at some of its organs like the knighthood, 
Ezinne [mother of faith] and Ezinna [father of faith], titles that are gradually becoming means of segregation and discrimination between the rich and poor members of the church.

- Charity to the poor is a social responsibility of the church. The church should take more practical steps towards economic empowerment of its members or non-members. This could be done by setting up more skill acquisition centres in different places to help train its people to be self-reliant. The church should also try to locate very poor people among its members and non-members and should be sending food and other basic necessities of life to them.

- The Catholic Church in Nigeria should make the welfare of the poor its main concern rather than infrastructures that most of the time impoverish the faithful by directly or indirectly forcing them to contribute money for such structures. In many cases, people who do not meet up with such payment are not accorded their rights, especially at death. This is another way of entrenching poverty among the masses.

- The early missionaries that came to Nigeria built schools and hospitals to help the poor. They helped educational development of members coupled with evangelism. They empowered their members through education. Presently, however, the schools and hospitals owned by the church more often are more expensive than government-owned ones, thereby placing them out of reach to the poor. Such facilities seem to be solely for profit-making and should be discouraged.

- The church must encourage and sustain at all levels the principle of subsidiarity, which protects the particular right and competencies of individuals against the excessive domination by societies as well as the competencies of minor associations against oppressive and totalitarian claims of a larger society.

- Poverty reduction is the bedrock of nation-building and mark of civilisation, and the Nigerian government should be serious in implementing its poverty reduction programmes.

\section{Conclusion}

This article has discussed poverty reduction in Nigeria. It sees poverty reduction as an issue that the government cannot toy with because of what the situation portends for the country. It recognises the various programmes designed by the Nigerian government at one time or the other to address the needs of the poor without changing the situation. Instead, poverty remains high in the country. It stressed the important but insufficient roles the Catholic Church in Nigeria has played in reducing poverty in the country. It also highlighted the constraints to the church's poverty reduction efforts. It is on this note that the article insists that poverty reduction should be everybody's concern and most importantly the government. Poverty reduction is the bedrock of nation-building and a mark of civilisation. It should be the primary assignment of the government because it helps to build peaceful coexistence among the citizens and sustains the rule of law. What the Nigerian government needs is the will power to tackle poverty as an evidence of good governance so as to cement Nigeria's nascent democracy.

\section{Acknowledgements Competing interests}

The authors declare that they have no financial or personal relationships which may have inappropriately influenced them in writing this article.

\section{Authors' contribution}

N.G.O. conceptualised and developed the work. L.O. edited and added more information to the work. F.U. edited and added more information to the work. All authors approved the final version of the manuscript.

\section{References}

Achunike, H.C., 2004, 'Developing the Nigerian nation through Justice Development and Peace Commission of the Catholic Church', in M.I. Okwueze (ed.), Religion and societal development, pp. 131-141, Merit International Publications, Lagos.

ActionAid Nigeria, 2015, Corruption and poverty in Nigeria: A report, ActionAid Nigeria, Abuja.

Ajulor, V.O., 2013, 'Policy implementation and rural poverty reduction in Nigeria (an analysis of the national poverty eradication programme (NAPEP) in Ado-Odo Ota local government area, Ogun state)', Paper presented at 1st Annual International Interdisciplinary Conference, AllC, Azores, Portugal, 24-26th April.

Aidelunuoghene, O.S., 2014, 'The paradox of poverty in Nigeria: What an irony', Research Journal of Finance and Accounting 5(4), 116-122.

Ani, C., Chukwuelobe, M. \& Nwankwo, A., 2015, 'Partnership between the state and the church: Contextualizing Nigerian faith-based vehicles as poverty reduction tools in the millenium', Open Journal of Political Science 5, 58-67. https://doi. org/10.4236/ojps.2015.52006

Antai, A.S. \& Anam, B.E., 2014, 'National poverty eradication programme and poverty reduction in Nigeria: Empirical investigation of the programme impact', Cross River State Developing Country Studies 4(20), 58-64.

Ayegba, U.S., 2015, 'Unemployment and poverty as sources and consequence of insecurity in Nigeria: The Boko haram insurgency revisited', African Journal of Political Science and International Relations 9(3), 90-99. https://doi.org/10.5897/ AJPSIR2014.0719

Barnes, A., 2010, 'Poverty eradication, millennium development goals and sustainable development in Nigeria', Journal of Sustainable Development 3(4), 138-144.

Catholic Bishops Conference Condemns Outbreak of Bloody Conflicts, Tasks Government to Stop the Ugly Trend, 2014, viewed 17 January 2018, from http:// sundiatapost.com

Catholic Diocese donates relief materials to IDPs in Nasarawa State, viewed 28 February2018, from https://www.vanguardngr.com

Catholic women organizations, viewed from http://www.stanthonysurulere.org

Ekpe, A., 2011, 'Poverty alleviation in Nigeria through capitalism economic framework: Problems and challenges', Journal of Sustainable Development in Africa 13(2), 181-191 Clarion University of Pennsylvania, Pennsylvania, PA.

Federal Republic of Nigeria (FRN), 2001, A Blueprint for the scheme of national poverty eradication program (NAPEP), Abuja, Federal Republic of Nigeria.

Francis, 2013, Evangelii Gaudium: Apostlic exhortation on the proclamation of the gospel in today's world, Libreria Editrice Vaticana, Rome.

Gordon, D., 2005, 'Indicators of poverty \& hunger', in Expert Group Meeting on Youth Development Indicators, pp.1-13, United Nations Headquarters, New York, December 12-14.

Ighadalo, A., 2012, 'Poverty and sustainable socio-economic development in Africa: The Nigeria experience', European Scientific Journal 8(26), 51-65.

International Food Policy Research Institute, 2010, Quantitative analysis of rural poverty in Nigeria, IFPRI, Abuja.

International Fund for Agricultural Development, 2012, Enabling poor rural people overcome poverty in Nigeria, IFAD, Abuja.

John XXIII, 1961, 'Encyclical letter Mater et Magistra, Encyclical Letter', AAS (Acta Apostolicae Sedis) LIII(8), 401-464.

John Paul II, 1981, Encyclical letter Laborem Exercens, AAS 73, 577-647.

John Paul II, 1988, Encyclical letter Sollicitudo Rei Socialis, AAS 80, 513-586. 
Kammer, F., 1991, Doing FaithJustice: An introduction to Catholic social thought, Paulist Press, New York.

Leo XIII, 1891, Encyclical letter Rerum novarum, Acta Sanctae Sedis 23, 641-670.

National Bureau of Statistics. HNLSS, 2010, Nigeria poverty profile, Abuja, Federal Republic of Nigeria.

National Institute for Policy and Strategic Studies, 2016, 'Strengthening institutional mechanisms for poverty reduction and inclusive development in Nigeria (Abridged Report presented to the President)', Senior Executive Course 38, 1-40, viewed 10 July 2017, from nipsskuru.gov.ng/.../STRENGTHENING-INSTITUTIONALMECHANISMS-FOR-P.

Obadan, M.I., 2002, 'Poverty reduction in Nigeria: The way forward', CBN Economic \& Financial Review 39(4), 159-188.

Oborji, F., 2012, 'The church and practice of charity to the poor: A missiological approach', in U.J. Njoku \& S.O. Anyanwu (eds.), In the service of charity and truth.
Essay in Honour of Lucius Ugorji, pp.169-202, Internationaler Verlag der Essay in Honour of Lucius
Wissenschaften, Peterlang.

Odeh, M., 2011, 'Deregulation policy in the downstream oil sector and the Nigerian economy', Journal of Social Science and Public Policy 3, 87-100.

Olubitan, A.A., 2014, 'The impact of Christianity on poverty alleviation: A case study of the Roman Catholic Church in Nigeria', PhD thesis, Department of Religion, University Of Ilorin, Nigeria.
Oluwatoyin, D., 2014, 'Women and poverty alleviation programmes in Nigeria: The Napep approach', Academic Journal of Interdisciplinary Studies 2(3), 515-521. https://doi.org/10.5901/ajis.2013.v2n3p515

Onwuliri, C.E., 2008, 'The Church as an agent of progress and development', in I.M. Onyeocha (ed.) The Church as an agent of progress and development: CIP jubilee essays, pp. 70-83, Imo State University Press, Owerri.

Pacelli school for the blind and partially sighted, 2015, viewed 28 February 2018 from www.educationinnovations.org>program

Paul VI, 1967, 'Encyclical letter Populorum Progressio', AAS 59, 65-289.

Paul VI, 1975, Apostolic exhortation Evangelii Nuntiandi, viewed 25 February 2015, from http://w2.vatican.va/content/paul-vi/en/apost_exhortations/documents/ hf_pvi_exh_19751208 evangelii-nuntiandi.html

Pius XI, 1931, 'Encyclical letter Quadragesimo', AAS 23, 177-228.

Taiwo, J.N. \& Agwu, M.N., 2016, 'Problems and prospect of poverty alleviation programmes in Nigeria', International Journal of Business and Management Review 4(6), 18-30.

The Catholic Bishops' Conference of Nigeria, 2014, Church and state partnership in the provision of quality Education, viewed 28 February 2018, from http://www.cbcnng.org/

Ucha, C., 2010, 'Poverty in Nigeria: Some dimensions and contributing factors', Global Majority E-Journal 1(1), 46-56. 